\section{SUMMARY}

Superoxide dismutase activity was determined in blood and lung tissue from adults and various infant groups. Enzyme activity in human fetuses and infants was significantly lower than in adults. Similarly, SOD activity was related to age in rats and rabbits with much lower activity found in late fetal animals compared with the adult animals. No significant differences in enzyme activity, however, were seen between ( 1 ) infants with IRDS/HMD and their premature peers without IRDS/HMD and between (2) premature infants and full term infants.

Experiments in which animal lung tissue was exposed either to $80-85 \%$ oxygen in vivo or $100 \%$ oxygen in vitro demonstrated an enhancement of pulmonary SOD activity in response to this hyperoxic challenge. In the rat, the ability to increase pulmonary SOD activity under hyperoxic conditions was age related, with the maximum effects occurring during the first 18 days of life.

These data suggest that SOD is an enzyme for which increasing activity associated with maturation may be obligatory to newborn lung for the provision of protection against the relative hyperoxia of extrauterine life.

\section{REFERENCES AND NOTES}

1. Aust, S. D., and Peterson, T. C.: NADPH-dependent lipid peroxidation catalyzed by purified NADPH-cytochrome $c$ reductase from rat liver microsomes. Biochem. Biophys. Res. Commun., 48: 789 (1972).

2. Avery, M. E.: What is BPD? Human Pathol., I: 321 (1970)

3. Babior, B. M., Kipnes, R. S., and Curnutte, J. T.: The production by leucocytes of superoxide: A potential bacteriocidal agent. J. Clin. Invest., 52:741 (1973)

4. Cederberg, A., Hellsten, S., and Miorner, G.: Oxygen treatment and hyaline pulmonary membranes in adults. Acta Pathol. Microbiol. Scand., 64: 450 (1965).

5. Crapo, J. D., and Tierney, D. F.: Superoxide dismutase and pulmonary oxygen toxicity. Amer. J. Physiol., 226: 1401 (1974).

6. Cronin, S. R., and Giri, S. N.: Effects of pulmonary irritants on DNA, ATPase activity and histamine on rat lung. Proc. Soc. Exp. Biol. Med., 146: 120 (1974)

7. Estabrook, R. W., Peterson, J., Baron, J., and Hildebrandt, A.: The spectrophotometric measurement of cytochromes in turbid suspensions. Methods Pharmacol., 2: 321 (1973).

8. Fridovich, I.: Quantitative aspects of the production of superoxide anion radical by milk xanthine oxidase. J. Biol. Chem., 245: 4053 (1970).

9. Gerschman, R.: Oxygen in the Animal Organism (MacMilian, New York, 1964).

10. Kauffman, S. L., Burri, P. H., and Weibel, E. R.: The postnatal growth of the rat lung. II. Autoradiography. Anat. Rec., 180: 63 (1974).

11. King, R. J.: The surfactant system of the lung. Fed. Proc., 33: 2238 (1974).
12. Knowles, P. F., Gibson, J. F., Pick, F. M., and Bray, R. C.: Electron-spin-resonance evidence for enzymic reduction of oxygen to a free radical, the superoxide ion. Biochem. J., 111: 53 (1969).

13. Kyle, J. D.: The effects of $100 \%$ oxygen inhalation on adult and newborn rat lungs. South. Med. J., 58: 1952 (1965).

14. Lavelle, F., Michelson, A. M., and Dimitryevic, L.: Biological protection by superoxide dismutase. Biochem. Biophys. Res. Commun., 55: 350 (1973).

15. Matsubara, T., and Shibata, S.: Evaluation of the internationally standardized method for haemoglobinometry. Clin. Chim. Acta, 23: 427 (1969).

16. McCord, J. M., Beauchamp, C. O., Goscin, S., Misra, H. P., and Fridovich, I.: Superoxide and superoxide dismutase. In: Oxidases and Related Redox Systems (University Park Press, Baltimore, 1973).

17. McCord, J. M., and Fridovich, I.: The reduction of cytochrome $c$ by milk xanthine oxidase. J. Biol. Chem., 243: 5753 (1968)

18. McCord, J. M., and Fridovich, I.: Superoxide dismutase: An enzymic function for erythrocuprein (hemocuprein). J. Biol. Chem., 244: 6049 (1969).

19. Misra, H. P., and Fridovich, I.: The role of superoxide anion in the autooxidation of epinephrine and a simple assay for superoxide dismutase. J. Biol. Chem., 247: 3170 (1972)

20. Misra, H. P., and Fridovich, I.: The univalent reduction of oxygen by reduced flavins and quinones. J. Biol. Chem., 247: 188 (1972).

21. Polgar, G., Antagnoli, W., Ferrigan, L. W., Olartin, E. A., and Gregg, W. P. The effect of chronic exposure to $100 \%$ oxygen in newborn mice. Amer. $\mathbf{J}$. Med. Sci., 252: 580 (1966).

22. Richards, G. M.: Modifications of the diphenylamine reaction giving increased sensitivity and simplicity in the estimation of DNA. Anal. Biochem., 57: 369 (1974).

-23. Saltzman, H. A., and Fridovich, 1.: Oxygen toxicity. Introduction to a protective enzyme: superoxide dismutase. Circulation, 48: 921 (1973).

24. Shanklin, D. R.: A general theory of oxygen toxicity in man. Perspect. Biol. Med., 13: $80(1969)$.

25. Shanklin, D. R.: Oxygen and the lungs of newborn infants. Int. J. Clin. Pharmacol., 5: 20 (1971)

26. Van Hien, P., Kovacs, K., and Matkovics, B.: Properties of enzymes: Study of superoxide dismutase activity change in human placenta of different ages. Enzyme, 18: 341 (1974)

27. Weibel, E. R.: Oxygen effects on lung cells. Arch. Int. Med., 128: 54 (1971).

28. The authors gratefully acknowledge the help and cooperation of members of the Department of Pathology and the ICU of the Department of Pediatrics at the University of Iowa Medical Center. We would also like to thank Mr. Doran Pearson for his expert technical assistance.

29. Dr. A, P. Autor is aided by a Basil O'Connor Starter Grant from the National Foundation-March of Dimes.

30. Dr. R. J. Roberts is a recipient of a Faculty Development Award in Clinical Pharmacology from the Pharmaceutical Manufacturer's Association.

31. This research was supported by United States Public Health Service Research Grant NIGMS 12675 and Trainee Grant 5701HL5577-13.

32. Requests for reprints should be addressed to: A. P. Autor, Ph.D., The Toxicology Center, Department of Pharmacology, The University of Iowa, lowa City, Iowa 52242 (USA)

33. Accepted for publication October 15, 1975

Copyright (c) 1976 International Pediatric Research Foundation, Inc.

Printed in U.S.A.

Pediat. Res. 10: 158-164 (1976)
Amino acid metabolism glycogen gluconeogenesis

liver metabolic development

phosphoenolpyruvate carboxykinase activity starvation

\title{
Utilization of Dietary Amino Acids for Energy Production in Neonatal Rat Liver
}

\author{
PATRICIA KREUTLER WHITE ${ }^{(56)}$ AND SANFORD A. MILLER
}

Department of Nutrition and Food Science, Massachusetts Institute of Technology, Cambridge, Massachusetts, USA

\section{Extract}

The 3-day-old rat has a high basal level of phosphoenolpyruvate carboxykinase (PEPCK), the activity of which is not increased upon starvation. The lower basal activity of the enzyme in 19-day-old rat liver can, however, be stimulated by starvation. Serum glucose levels increased from 3 days to 19 days of age, with a decrease to adult levels. Liver glycogen concentration increased from 3 days to 19 days of age, with no additional increase observed at 3 months. There was a decrease with age in the specific activity of liver glycogen (from $\left[{ }^{14} \mathrm{C}\right]$ alanine and $\left[{ }^{14} \mathrm{C}\right]$ leucine). In fed rats given $\left[{ }^{14} \mathrm{C}\right]$ alanine, ${ }^{14} \mathrm{CO}_{2}$ expiration tended to decrease with age. The ${ }^{14} \mathrm{CO}_{2}$ produc- 
tion from $\left[{ }^{14} \mathrm{C}\right]$ leucine was less than that from alanine, and also decreased with age. Three-day-old rats showed no change in serum glucose when starved for $4 \mathrm{hr}$. On the other hand, 19-day-old rats responded with a decrease in serum glucose; although the adult animal's basal level of serum glucose was less than that of the 19-day-old rats, starvation for $15 \mathrm{hr}$ also caused a significant decrease. There was no statistically significant difference in liver glycogen concentration between the fed and starved 3-day-o!d animals. Liver glycogen concentration in the 19-day-old adult rats was affected, however, by starvation. The 3-day-old rat showed no significant change in incorporation of labeled amino acids into liver glycogen during starvation. Starvation resulted in a tremendous increase in the specific activity of hepatic glycogen in the 19-day-old and adult rats.

Starvation decreased the percentage of labeled amino acid expired as ${ }^{14} \mathrm{CO}_{2}$. The proportion expired also decreased with age.

Urinary nitrogen concentration increased significantly between 3 and 19 days of age. Starvation produced differential effects in the animals, with no change being observed in either the 3-day or adult rats; a decrease was observed in the 19-day-old animals. Urinary nitrogen concentration was measured in adult carbohydratedeprived rats and was significantly higher than control values. These rats had a high gluconeogenic rate, reflected in the increased urinary nitrogen concentration.

The young rat is at the mercy of a continuous supply of substrate in that it has a limited capacity for directing substrate flow within the liver in response to dietary changes.

\section{Speculation}

The relatively high dietary protein requirement for the neonatal rat may be a reflection of the utilization of amino acids not only for protein synthesis, but also for energy, as well as the need to conserve nitrogen as a source of nucleic acids for hyperplastic growth.

The utilization of dietary amino acids for synthesis of structural and functional proteins is of unquestionable importance during the early development of the growing animal. Miller (26) examined the rates of protein synthesis in various organs of the neonatal rat and observed distinct patterns of uptake of $\left[{ }^{14} \mathrm{C}\right]$ leucine into total organ protein, which coincided with an increase in the size of the total tissue free amino acid pool. Munro (30) has advanced the hypothesis that a change in the size of the free amino acid pool regulates tissue protein synthesis; it therefore becomes important to determine factors which in turn regulate the size of the pool. An increase in the concentration of tissue amino acids may be a reflection of several components of a regulated system. These may include an increased supply of dietary amino acids, a change in the catabolic rate of particular amino acids or hepatic proteins, and/or a change in their utilization.

Among the significant uses for amino acids during the early phase of life is gluconeogenesis. Hepatic gluconeogenesis is known to operate at a high basal rate early in postnatal development of the rat. Liver enzymes associated with gluconeogenesis appear postnatally $(3,4,6,10,32,35,45)$, and phosphoenolpyruvate carboxykinase (EC. 4.1.1.32), reportedly the rate-limiting enzyme in the gluconeogenic pathway (25), has been demonstrated to exhibit greater activity in the suckling animal than in the adult. In vitro studies with ${ }^{14} \mathrm{C}$-labeled substrates (39) and an in vivo study with $\left[{ }^{14} \mathrm{C}\right]$ lactate $(42)$ have demonstrated that infant rat liver is highly active in the conversion of noncarbohydrate precursors to glucose and glycogen. Thus far, no definitive information quantitating the in vivo importance of this pathway in the neonatal rat using amino acids as precursors has been available.

To investigate this problem, we used 3-day-, 19-day-, and 3-month-old rats to study the in vivo distribution of orally administered $\left[{ }^{14} \mathrm{C}\right]$ leucine or $\left[{ }^{14} \mathrm{C}\right]$ alanine into $\mathrm{CO}_{2}$ and liver glycogen under fed and starved conditions. We also examined the activity of hepatic PEPCK under these conditions.
METHODS AND MATERIALS

\section{ANIMALS}

All rats used in these studies were of the Sprague-Dawley strain from the Charles River Breeding Laboratories, Wilmington, Mass. Lactating mothers with 1-day-old pups were shipped to our animal facilities. Litters were randomized and culled to eight pups, and animals were housed individually in plastic tubs with a bedding of wood chips and covered with wire mesh tops. The room was temperature $\left(68-72^{\circ} \mathrm{F}\right)$ and humidity $(50 \%)$ controlled, and lights were on from 6:00 AM to 6:00 PM. Animals were provided with diet (46) and tap water ad libitum. Those rats to be studied as adults were weaned at 21 days and placed in individual wire cages with food and water provided ad libitum. They were weaned on one of two agar gel diets: our standard $25 \%$ casein diet (46) or a high fat, low carbohydrate diet (47), resembling rat's milk in composition (11).

\section{METHODS OF PROCEDURE}

The activity of hepatic PEPCK was investigated in 3- and 19-day-old animals during a 6-hr staryation period. Periods of starvation were imposed by placing 3-day-old rats with nonlactating foster mothers; the 19-day-old pups were removed from their lactating mother and placed in cages without access to food. Starvation began at 4:00 AM, with pups starved at hourly intervals thereafter. All pups were killed at 10:00 AM, including pups who had remained with lactating mothers until the time of death. Pups were decapitated and the livers removed, weighed, and frozen on Dry Ice; livers were stored at $-40^{\circ}$ until the time of assay. Single livers were used for enzyme determinations, and three pups were included in each group.

To follow the distribution of orally administered uniformly labeled $\left[{ }^{14} \mathrm{C}\right]$ leucine $(327 \mathrm{mCi} / \mathrm{mmol})$ or $\left[{ }^{14} \mathrm{C}\right]$ alanine $(156 \mathrm{mCi} /$ mmol) (48) into $\mathrm{CO}_{2}$ and liver glycogen, we studied animals of 3 days, 19 days, and 3 months of age. Each group was further subdivided into "fed" and "starved" (49).

Three-day-old rats were considered to be fed when they were removed from the nest $1 \mathrm{hr}$ before administration of the radioactive amino acid and the start of $\mathrm{CO}_{2}$ collection. They were fed $0.5 \mu \mathrm{Ci}{ }^{14} \mathrm{C}$-amino acid in $0.2 \mathrm{ml}$ of $10 \%$ protein formula (50) by intubation (29). They were placed, individually, in a glass metabolism cage (details given below) and then killed by decapitation. Starved rats were also removed from their lactating mother $\mathrm{l} \mathrm{hr}$ before the beginning of the experiment, but received $0.5 \mu \mathrm{Ci}$ labeled amino acid in $0.2 \mathrm{ml}$ distilled water.

The 19-day-old rats were similarly treated, receiving $1.0 \mu \mathrm{Ci}$ labeled amino acid in $0.5 \mathrm{ml}$ formula or distilled water. Fed rats were treated as were the 3-day-old rats; starved rats were without food for $15 \mathrm{hr}$ before the administration of radioactive amino acid.

Adult animals, 3-4 months old, had been weaned at 21 days on one of two diets $(46,47)$ on which they were permitted to feed ad libitum. Two microcuries of $\left[{ }^{14} \mathrm{C}\right]$ amino acid were given in $0.5 \mathrm{ml}$ formula or distilled water. Starved rats had been deprived of food for $48 \mathrm{hr}$ before the experiment.

\section{APPARATUS}

Two different types of apparatus were used for the experiments, one for 3-day-old rats, and another larger model (5l) for the 19-day- and 3-month-old animals. The smaller model, designed in our laboratory, has been described recently (43). The expired air was collected into $15 \mathrm{ml}$ ethanolamine-methyl Cellosolve $(1: 2)$, which trapped the expired $\mathrm{CO}_{2}$ (34).

All animals were killed by decapitation. Trunk blood was collected and centrifuged at 2,500 rpm for $25 \mathrm{~min}$. Serum was stored at $-40^{\circ}$. Urine was collected and analyzed immediately for urinary nitrogen concentration. Livers were removed, bl $l^{\prime}$ weighed, and frozen on Dry Ice. Storage at $-40^{\circ}$ was mair until analyses were carried out. 


\section{CHEMICAL ANALYSES}

PEPCK activity was determined according to the methods of Berndt and Ulbrich (5) and Czok and Eckert (9). Serum glucose concentration was measured by an enzymatic micromethod (52). Hepatic glycogen concentration was measured by the method of Good et al. (15) in which acid hydrolysis of the glycogen was followed by estimation of glucose by the enzymatic method. An aliquot of neutralized hydrolysate was taken and counted with $15 \mathrm{ml}$ Aquasol (48) in a Packard Tri-Carb scintillation spectrometer, model 2002. To correct for the varying size of the hepatic free amino acid pools under the different experimental conditions, the relative specific activity of the newly synthesized glycogen was calculated as follows: disintegrations per min per $\mathrm{mg}$ glycogen $\div$ disintegrations per min per $\mu \mathrm{mol}$ alanine (or leucine) present in the liver free amino acid pool. A gas-liquid chromatography method was used for analyses of free amino acids as their $N$-trifluoroacetyl- $n$-butyl esters (14). Total urinary nitrogen, contributed by both ammonia and urea, was determined by the microdiffusion method of Conway (7).

\section{RESULTS}

\section{RESPONSE OF HEPATIC PEPCK TO STARVATION}

During the 6-hr period of starvation, none of the activities measured in 3-day-old rat liver was statistically different from the control value of $126 \pm 20 \mu \mathrm{mol} \mathrm{PEP} / \mathrm{hr} / \mathrm{g}$ (mean $\pm \mathrm{SEM}$ ). On the other hand, 19-day-old rats responded to starvation with a significant $(P<0.05)$ increase from the control level of $88 \pm 17$ $\mu \mathrm{mol} \mathrm{PEP} / \mathrm{hr} / \mathrm{g}$ to $296 \pm 8$ at $6 \mathrm{hr}$. Relative changes in activity are shown in Figure 1. Thus, the 3-day-old rat has a high basal level of PEPCK whose activity is not increased upon starvation. The lower basal activity of the enzyme in 19-day-old liver can, however, be stimulated by starvation.

\section{EFFECT OF AGE ON UTILIZATION OF $\left[{ }^{14} \mathrm{C}\right]$ AMINO ACIDS}

Serum glucose and liver glycogen concentration increased from 3 to 19 days of age. Although adult rats demonstrated a decrease in

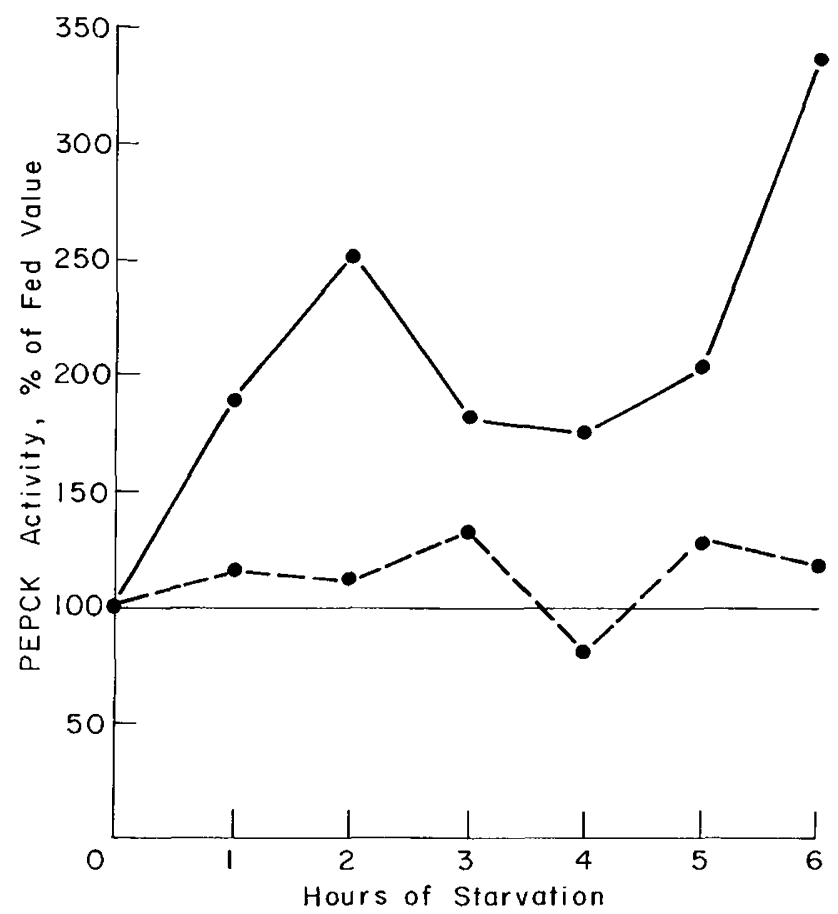

Fig. 1. Response of hepatic phosphoenolpyruvate carboxykinase (PEPCK) activity to starvation. Activities are given as percentages of the fed control values: 3-day-old rats (- - ), 19-day old rats ( - ). Three animals were used for each determination.
Table 1. Effect of age and nutritional status on serum glucose and liver glycogen ${ }^{1}$

\begin{tabular}{lcr}
\hline \multicolumn{1}{c}{ Group } & $\begin{array}{c}\text { Serum glucose, } \\
\mathrm{mg} / 100 \mathrm{ml}\end{array}$ & $\begin{array}{c}\text { Liver glycogen, } \\
\mathrm{mg} / \mathrm{g}\end{array}$ \\
\hline $\begin{array}{l}\text { 3-day-old } \\
\text { Fed }\end{array}$ & $94 \pm 6$ & $11.1 \pm 1.9$ \\
$\quad$ Starved $4 \mathrm{hr}$ & $92 \pm 4$ & $5.8 \pm 1.8$ \\
19-day-old & $188 \pm 10^{2}$ & $23.9 \pm 2.6^{2}$ \\
$\quad$ Fed & $138 \pm 3^{3}$ & $6.5 \pm 1.7^{3}$ \\
Starved 15 hr & $155 \pm 8^{4}$ & $19.0 \pm 2.3$ \\
3-month-old & $102 \pm 8^{3}$ & $0.7 \pm 0.1^{3}$ \\
Fed & $168 \pm 16$ & $19.8 \pm 1.0$ \\
Starved 48 hr & & \\
-CHO & &
\end{tabular}

${ }^{1}$ Mean $\pm \operatorname{SEM}(n=6)$.

${ }^{2}$ Different from 3-day fed value, $P<0.01$.

${ }^{3}$ Different from fed control, $P<0.01$.

Different from 19-day fed value, $P<0.01$.

${ }^{5}$ Animals fed high fat, low carbohydrate diet.

basal serum glucose level compared with 19-day-old animals $(P<$ 0.05 ), no further change was observed in liver glycogen concentration (Table 1). Adult rats fed a low carbohydrate diet showed levels of serum glucose and liver glycogen concentration similar to those controls, which suggests the utilization of noncarbohydrate precursors for carbohydrate synthesis.

There was a decrease with age in the specific activity of liver glycogen $(P<0.01)$ (Table 2). As expected, the incorporation of $\left[{ }^{14} \mathrm{C}\right]$ leucine into glycogen was less than that of $\left[{ }^{14} \mathrm{C}\right]$ alanine, but apparently the young animal can convert a portion of dietary leucine into a carbohydrate energy source. The carbohydratedeprived adults given $\left[{ }^{14} \mathrm{C}\right]$ alanine demonstrated greater activity in this liver fraction compared with the normally fed adults.

In fed rats given $\left[{ }^{14} \mathrm{C}\right]$ alanine, ${ }^{14} \mathrm{CO}_{2}$ expiration, as a percentage of the absorbed dose, tended to decrease with age, although differences were not statistically significant because of the small number of animals used (Fig. $2 A$ ). The ${ }^{14} \mathrm{CO}_{2}$ production from $\left[{ }^{14} \mathrm{C}\right]$ leucine was, as anticipated, less than that from alanine, and also tended to decrease with age (Fig. $2 B$ ).

\section{EFFECTS OF STARVATION ON UTILIZATION OF $\left[{ }^{14} \mathrm{C}\right]$ AMINO ACIDS}

Although starvation for 15 or $48 \mathrm{hr}$ produced a decrease $(P<$ 0.01 ) in serum glucose of 19-day-old and adult rats, respectively, no change in serum glucose was observed in 3-day-old rats which were starved for $4 \mathrm{hr}$ (Table 1). Similarly, there were no statistically significant differences in liver glycogen concentration between the fed and starved 3-day-old animals. Liver glycogen concentration in the 19-day-old and adult rats was affected, however, by starvation, with a significant $(P<0.01)$ decrease apparent (Table 1).

When specific activity of liver glycogen was considered, nutritional manipulation had differential effects on the different age groups (Table 2). The 3-day-old rat showed no significant change in incorporation of labeled amino acid into liver glycogen during starvation, whereas food restriction resulted in an increase in the relative specific activity of hepatic glycogen in both the 19-day-old and adult rat.

Starvation tended to decrease the percentage of labeled amino acid expired as $\mathrm{CO}_{2}$ at all ages (Fig. 3, $A$ and $B$ ). Starved rats appeared to have a higher initial oxidation rate than fed animals, but this may be primarily a function of the $\left[{ }^{14} \mathrm{C}\right]$ amino acid being given in distilled water rather than in formula, thereby increasing the absorption rate of the amino acid.

Urinary nitrogen concentration. an apparent measure of protein catabolism, increased significantly $(P<0.01)$ between 3 and 19 days of age, with no further increase noted at 3 months (Table 3 ). 
Starvation produced differential effects in the animals, with no change being observed in either the 3-day- or 3-month-old rats. A decrease was observed in the 19-day-old animals.

An interesting observation was made when urinary nitrogen excretion was measured in adult carbohydrate-deprived rats. Urinary nitrogen concentration was significantly higher $(P<$ $0.01)$ than adult control values. These rats had a high gluconeogenic rate (indicated by specific activity of liver glycogen), and this is reflected in the increased urinary nitrogen concentration. This relationship is not found in the 3-day-old rats, who also have a high basal gluconeogenic rate, but whose level of urinary nitrogen is low. It is possible that the nitrogen produced via gluconeogenesis in the infant animal is conserved in the forms of nucleic acids and their precursors, whereas, in the adult, increased excretion of nitrogen accompanies gluconeogenesis.

Table 2. Effect of age and nutritional status on specific activity of liver glycogen ${ }^{1}$

\begin{tabular}{|c|c|c|}
\hline \multirow[b]{2}{*}{ Group } & \multicolumn{2}{|c|}{ Substrate } \\
\hline & $\begin{array}{c}\begin{array}{c}{\left[{ }^{14} \mathrm{C}\right] \text { Alanine, }} \\
\mathrm{dpm} / \mathrm{mg} \text { glycogen }\end{array} \\
\frac{\mathrm{dpm} / \mu \mathrm{mol} \text { alanine }}{}{ }^{2}\end{array}$ & $\begin{array}{c}{\left[{ }^{14} \mathrm{C}\right] \text { Leucine, }} \\
\mathrm{dpm} / \mathrm{mg} \text { glycogen } \\
-\mathrm{dpm} / \mu \mathrm{mol} \text { leucine }\end{array}$ \\
\hline \multicolumn{3}{|l|}{ 3-day-old } \\
\hline Fed & $1.08 \pm 0.14$ & $0.37 \pm 0.025$ \\
\hline Starved $4 \mathrm{hr}$ & $0.98 \pm 0.33$ & $0.53 \pm 0.022$ \\
\hline \multicolumn{3}{|l|}{ 19-day-old } \\
\hline Fed & $0.15 \pm 0.03^{3}$ & $0.003 \pm 0.001$ \\
\hline Starved $15 \mathrm{hr}$ & $6.41 \pm 3.62$ & $0.032 \pm 0.015$ \\
\hline \multicolumn{3}{|l|}{ 3-month-old } \\
\hline Fed & $0.00 \pm 0.00^{3,4}$ & $0 \pm 0^{5}$ \\
\hline Starved $48 \mathrm{hr}$ & $0.25 \pm 0.17$ & $0 \pm 0$ \\
\hline$-\mathrm{CHO}^{6}$ & $0.28 \pm 0.22$ & $0 \pm 0$ \\
\hline
\end{tabular}

${ }^{1}$ Mean $\pm \operatorname{SEM}(n=3)$.

${ }^{2}$ Specific activity of amino acid in hepatic free amino acid pools.

${ }^{3}$ Different from 3-day fed value, $P<0.005$.

${ }^{4}$ Different from 19-day fed value, $P<0.01$.

${ }^{5}$ Different from 19-day fed value, $P<0.02$.

${ }^{6}$ Animals fed high fat, low carbohydrate diet.

\section{DISCUSSION}

The age of the animals studied in these experiments was an important consideration. Rats of 3 days, 19 days, and 3 months of age were selected for several reasons. Differences in protein metabolism have been demonstrated in 3-day- and 19-day-old rats (26). Also, gluconeogenesis has been reported to be high in the young animal and lower in the older rat (44). Adult animals were used to demonstrate metabolic differences between the developing and mature animal. Thus, the three groups represented three levels of development: immaturity, a transition state, and the mature adult.

The time periods chosen for starvation were selected for several reasons. Dams wander away from the nest for periods of time, and the pups may be without food for as long as 4-6 hr (37). By the end of "physiologic" starvation for $4 \mathrm{hr}$, no milk is found in the stomachs of 3-day-old rats. Also, previous work in this laboratory has demonstrated a breakdown of liver polysomes after a fast of 4 hr in neonatal rats $(27,38)$.

The starvation periods imposed on the older rats were also chosen on the basis of food content in their stomachs as well as on the liver polysome disaggregation known to occur at these times.

The adult animal has the capability to convert noncarbohydrate precursors to carbohydrates during starvation via the increased activity of transaminases and PEPCK $(13,16,20)$. Based on our results and those of others, it appears that under normal conditions, the infant rat has high levels of PEPCK. Our finding in preliminary studies that the basal activity of this regulatory enzyme decreases with age confirms the observations of Yeung et al. (45) and Hahn and Greenberg (17).

Observations of enzyme activity in our studies suggested that starvation increased the activity of hepatic PEPCK in 19-day-old rats, but not in 3-day-old rats (Fig. 1). It is well known that starvation also induces an elevation of hepatic PEPCK activity in adult rats $(12,20)$. The 19-day-old rat appears to respond, like the adult, to starvation with an increase in activity of the rate-limiting gluconeogenic enzyme. The increase in serum glucose and liver glycogen concentrations with age (Table 1 ) is probably a function of gluconeogenesis in early development, as well as an increase in dietary carbohydrate consumption as the animal is weaned onto the high carbohydrate diet of the adult. Our observation that the serum glucose level is higher in the 19-day-old rat than the adults is probably a result of two conditions: an increasing consumption of
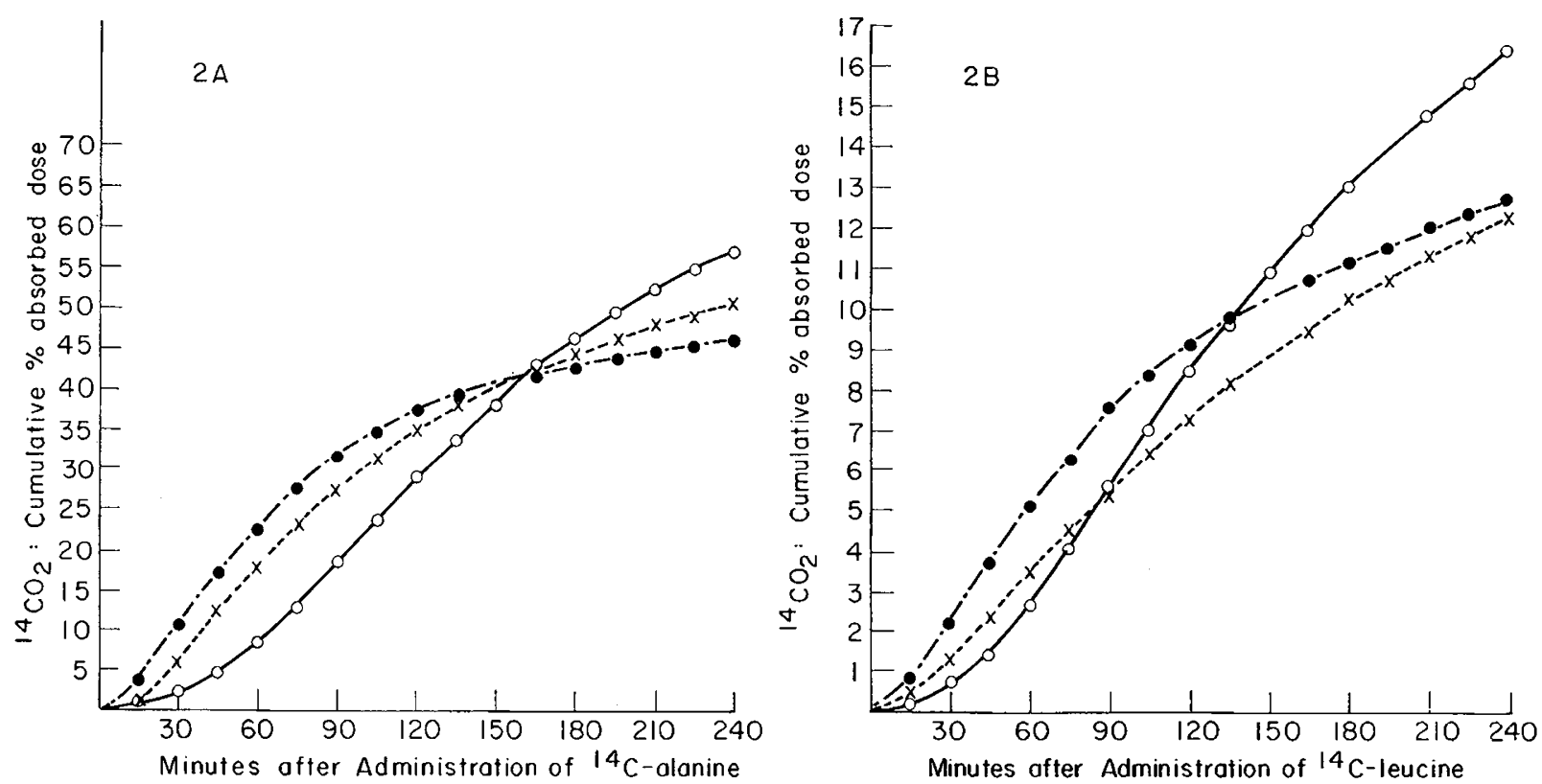

Fig. 2. $A:{ }^{14} \mathrm{CO}_{2}$ expiration in fed rats given $\left[{ }^{14} \mathrm{C}\right]$ alanine: 3-day-old $(\mathrm{O}-\mathrm{O})$, , 19-day-old $(\times---\times), 3$-month-old, $(\bullet--\bullet)$. Each point represents the mean of three determinations. $B:{ }^{14} \mathrm{CO}_{2}$ expiration in fed rats given $\left[{ }^{14} \mathrm{C}\right]$ leucine: symbols as in $A$. 

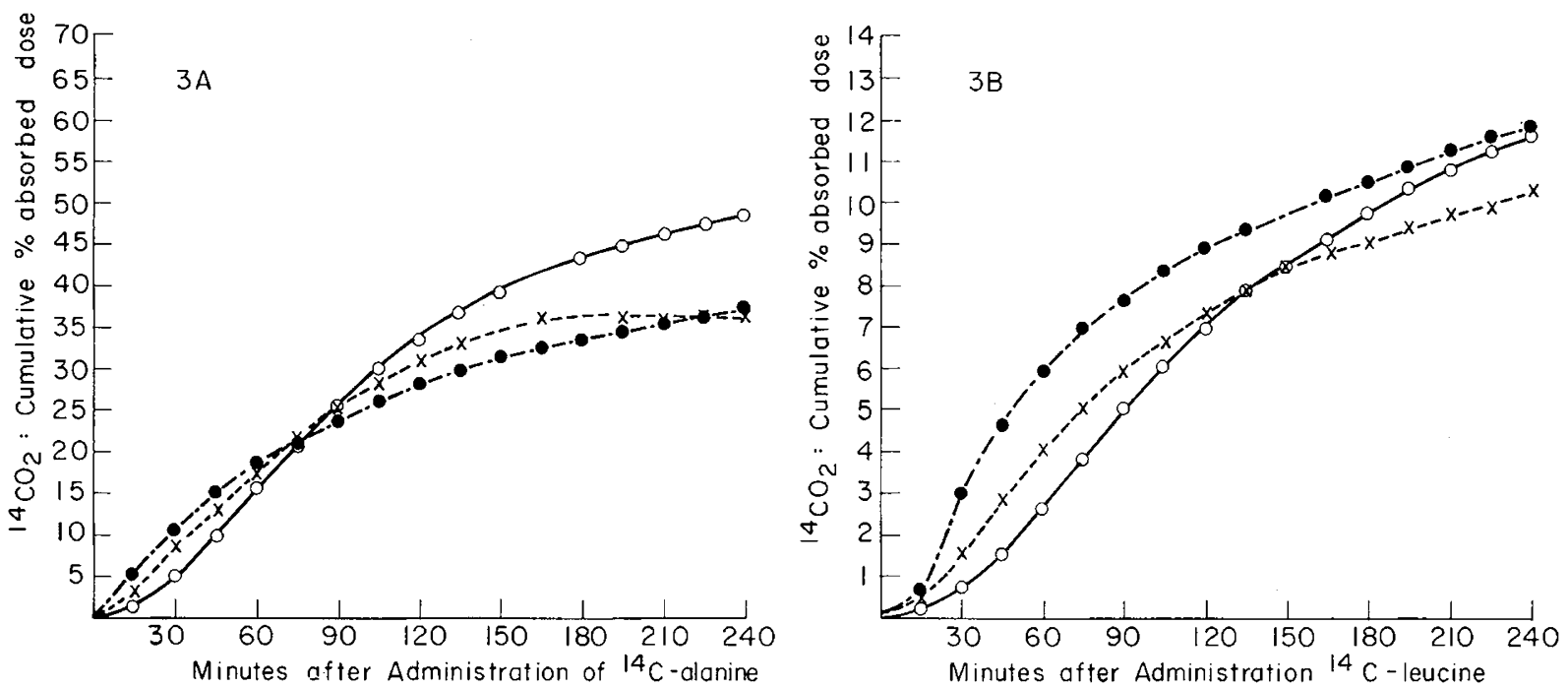

Fig. 3. $A:{ }^{14} \mathrm{CO}_{2}$ expiration in starved rats given $\left[{ }^{14} \mathrm{C}\right]$ alanine: symbols as in Figure $2 A \cdot B:{ }^{14} \mathrm{CO}_{2}$ expiration in starved rats given $\left[{ }^{14} \mathrm{C}\right]$ leucine: symbols as in Figure $2 A$.

Table 3. Effect of age and nutritional status on urinary nitrogen concentration $^{1}$

\begin{tabular}{lc}
\hline \multicolumn{1}{c}{ Group } & Urinary nitrogen, $\mathrm{mg} \mathrm{N} / \mathrm{ml}$ \\
\hline 3-day-old & \\
Fed & $4.7 \pm 0.5$ \\
Starved $4 \mathrm{hr}$ & $3.8 \pm 0.6$ \\
19-day-old & $11.3 \pm 0.5^{2}$ \\
Fed & $7.9 \pm 0.6^{3}$ \\
Starved 15 hr & \\
3-month-old & $13.4 \pm 2.3$ \\
Fed & $11.7 \pm 2.8$ \\
Starved 48 hr & $25.8 \pm 2.2^{3}$ \\
-CHO4 &
\end{tabular}

${ }^{1}$ Mean $\pm \operatorname{SEM}(n=3)$.

${ }^{2}$ Different from 3-day fed value, $P<0.01$.

${ }^{3}$ Different from fed control, $P<0.01$.

${ }^{4}$ Animals fed high fat, low carbohydrate diet.

dietary carbohydrate as the rat begins to sample the maternal diet, coupled with a still relatively high basal level of gluconeogenesis.

Thus during the early development of the rat a relatively high percentage of dietary amino acids is directed toward glycogen formation, as well as toward general oxidation. As the animal matures, his need to maintain a high basal rate of gluconeogenesis decreases as his intake of dietary carbohydrate increases $(17,40)$; there is a concomitant decrease in PEPCK activity (17).

Our results also indicate that metabolic patterns in young rats appear to be basically unchanged when periods of starvation are imposed upon them. An acute starvation period had no effect on the activity of PEPCK. Blood glucose and liver glycogen levels remained essentially the same as the control values. It appears that the combination of $(1)$ continued synthesis of carbohydrate from amino acids during starvation and (2) the relatively low utilization rate of blood glucose $(1,19,24,41)$ would explain the unaltered level of serum glucose found in these animals after $4 \mathrm{hr}$ of starvation. Glycogen synthesis from amino acids does not change during starvation of 3-day-old rats. Oxidation of amino acids decreases slightly. Urinary nitrogen concentration remains at the low levels of nonstarved rats.

In contrast, our results show that both 19-day- and 3-month-old rats respond dramatically to periods of starvation. Weanling rats demonstrate a large increase in the activity of PEPCK during $6 \mathrm{hr}$ of starvation. At the same time, liver glycogen levels decrease but it is obvious that active synthesis from amino acids is occurring, as measured by its specific activity.

In a recent paper, Aranda and Herrera (2) have found essentially the same effect, using pyruvate as substrate. In their experiments, all animals were starved for the same period of time $(24 \mathrm{hr})$, in contrast to our experiments in which starvition to the same metabolic state, referring to protein synthesis, was used. It is interesting to note that in both experiments starvation did not produce any increase in gluconeogenesis in the neonatal rat, although it did produce a significant rise in the adult, regardless of which substrate was used.

Comparison of the response of the different age groups to starvation, both in terms of PEPCK activity and the specific activity of glycogen synthesized from $\left[{ }^{14} \mathrm{C}\right]$ alanine, is given in Figure 4.

We wished to find out what the effect of weaning an animal onto the same type diet he consumed during the suckling period, i.e., high in fat and low in carbohydrate (18) would be. As has been shown in these studies, glycogen synthesis from amino acids is maintained at a rate higher than normally fed adult controls, and blood glucose and liver glycogen levels are normal. This indicates a greater utilization of noncarbohydrate substances for energy production.

Nitrogen excretion is generally considered to be a measure of protein and/or amino acid catabolism. The urea cycle is functional in rats older than about 14 days of age, as has been demonstrated by Illnerova and colleagues (22). The appearance of liver arginase and the increase in ornithine transcarbamylase at 14 days of age appears to be the trigger for operation of the cycle as the method of nitrogen removal from the liver (23).

As has been shown in these and other studies, urinary nitrogen concentration increases with age. When combined with the well known observation that urinary flow also increases with age (21), it is apparent that total urinary nitrogen excretion is lower in the neonate than the adult. Given that gluconeogenesis is high postnatally, what becomes of the nitrogen that is lost from the amino acids? Previous studies done in our laboratory indicated that the young animal tends to conserve nitrogen; nitrogen balance studies with 1-5-day-old rats showed that the rat maintained positive nitrogen balance even on a $0.6 \%$ protein diet $(8,27)$.

Recent unpublished studies (36) done in our laboratory demonstrated low hepatic levels of $\mathrm{NH}_{3}$ in both fed and 15-hr starved 6-day-old rats. Concentrations of $11.4 \pm 2.7$ and $12.2 \pm 3.4 \mathrm{mg}$ $\mathrm{NH}_{3}-\mathrm{N} / \mathrm{mg}$ DNA were measured in the two groups, respectively. Starvation for $15 \mathrm{hr}$ produced no change in this concentration $(P$ $>0.05$ ). It appears that the animal tends to conserve nitrogen compounds in its tissues. Possibly, the requirement for nucleic acid 
synthesis (33), necessary for a tissue in hyperplastic growth, serves as a sink for the nitrogen produced by gluconeogenesis or amino acid catabolism.

It is interesting to note that the carbohydrate-deprived adults, utilizing the process of gluconeogenesis from amino acids for energy production, have a significant increase in urinary nitrogen excretion, in contrast to the results obtained from the newborn rats.

This further suggests that the young animal utilizes the nitrogen rather than excreting it. If this is true, it is possible that the increased protein requirement of the neonatal rat is related not only to the demands of tissue protein synthesis, but also perhaps to the need of the neonatal rat for carbon for glucose, and nitrogen for nucleotide biosynthesis.

This is in contrast to the argument of Hahn and his colleagues that the high nitrogen requirement is principally for tissue protein synthesis and that all of the energy needs of the developing rat are met by the utilization of fat (19). In addition to the data provided in this study, support for our contention can also be calculated from measured food intake and energy requirements of growing rats.

As shown in Table 4, based upon earlier data from our laboratory (11), 54\% of dietary protein and $59 \%$ of dietary fat is not incorporated into body mass, and is either excreted or utilized for energy production. Hahn contends that since a maximum of 0.8 $\mathrm{cal} / 24 \mathrm{hr}$ can be obtained from protein, it is not a source of energy for the postnatal rat. Using our food intake data and the

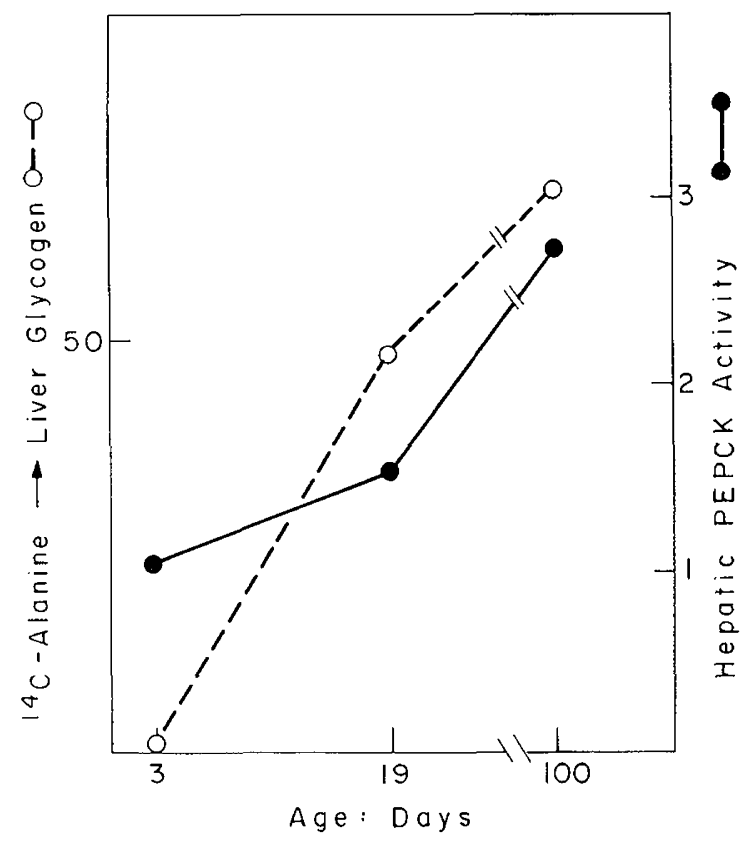

Fig. 4. Adaptation of gluconeogenesis to starvation during development. Starved to fed ratio of $\left[{ }^{14} \mathrm{C}\right] \mathrm{alanine}$ incorporation into liver glycogen $\left(\mathrm{O}-\mathrm{O}^{-}\right.$) and hepatic phosphoenolpyruvate carboxykinase (PEPCK) activity $(\mathbf{O}-\mathbf{O})$.

Table 4. Body composition of neonatal rats as related to dietary intake of protein and $\mathrm{fat}^{1}$

\begin{tabular}{lcc}
\hline & Fat, $\mathrm{mg}$ & Protein, $\mathrm{mg}$ \\
\hline Dietary intake & 3,640 & 2,800 \\
Accumulated into body mass $^{2}$ & 1,500 & 1,300 \\
Not accumulated into body mass & 2,140 & 1,500 \\
\hline
\end{tabular}

\footnotetext{
${ }^{1}$ Rats were fed $28 \mathrm{ml}$ of $10 \%$ protein formula from birth to 7 days of age.

${ }^{2}$ Change in amount from birth to 7 days of age.
}

observation that only a small proportion of nitrogen is excreted, we can calculate the same figures:

$$
\begin{aligned}
& \frac{1.5 \text { g protein }}{7 \text { days }} \times \frac{4 \text { cal }}{\text { g protein }}=\frac{6 \mathrm{cal}}{7 \text { days }}=0.9 \mathrm{cal} \text { from protein } / 24 \mathrm{hr} \\
& -\frac{2.1 \mathrm{~g} \mathrm{fat}}{7 \text { days }} \times \frac{9 \mathrm{cal}}{\mathrm{g} \mathrm{fat}}=\frac{18.9 \mathrm{cal}}{7 \text { days }}=2.7 \mathrm{cal} \mathrm{from} \mathrm{fat} / 24 \mathrm{hr}
\end{aligned}
$$

In contrast to Hahn's contention that dietary protein accounts for little of the caloric needs of the animal, we contend that the $25 \%$ of daily caloric needs provided by dietary protein is not an insignificant contribution. Moreover, if amino acid supply is limited, the animal's survival may be jeopardized not only by the lack of a nitrogen source necessary for protein synthesis and other essential metabolic compounds, but also by an energy deficit.

\section{SUMMARY}

That the infant rat maintains a higher gluconeogenic rate than the adult animal has been demonstrated clearly in this report. The concept of diet composition as an important regulator of the developmental process is an interesting one. The young animal requires dietary amino acids not just for growth, as has been previously assumed, but also as a source of energy. The relatively high dietary protein requirement may also be a reflection of the animal's need to conserve nitrogen as a source of nucleic acid for hyperplastic growth.

Also, this nonresponsiveness to short term starvation indicates that the young rat is at the mercy of a continuous supply of substrate, and that it has a limited capacity for directing substrate flow within the liver in response to dietary changes. Thus, survival in conditions of starvation is much more limited in the young animal than in the adult, who is able to recognize a stressful situation and switch his mode of operation from "maintenance" to "survival."

\section{REFERENCES AND NOTES}

1. Allen, D. T., Kornhauser, D., and Schwartz, R.: Glucose homeostasis in the newborn puppy. Amer. J. Dis. Child., 112: 343 (1966).

2. Aranda, A., and Herrera, E.: The effect of food deprivation on in vivo gluconeogenesis in the suckling rat. Hormone Metab. Res. 6: 381 (1974).

3. Ballard, F. J., and Hanson, R. W.: Phosphoenolpyruvate carboxykinase and pyruvate carboxylase in developing rat liver. Biochem. J., 104: 866 (1967).

4. Ballard, F. J., and Oliver, I. T.: Appearance of fructose-1,6-diphosphatase in postnatal rat liver. Nature, 195: 498 (1962)

5. Berndt, J., and Ulbrich, O.: A simplified method for determination of phosphoenolpyruvate carboxykinase activity. Anal. Biochem., 34: 282 (1970).

6. Burch, H. B. Lowry, O. H., Kuhlman, A. M., Skerjance, J., Diamant, E. J Lowry, S. R., and Von Dippe, P.: Changes in patterns of enzymes of carbohydrate metabolism in the developing rat liver. J. Biol. Chem., 238: 2267 (1963).

7. Conway, E. J.: An absorption apparatus for the microdetermination of certain volatile substances. II. The determination of urea and ammonia in body fluids. Biochem. J., 27: 430 (1933).

8. Czajka-Narins, D. M., Miller, S. A., and Browning, A. M.: Studies of the protein requirement of the neonatal rat. J. Nutr., 103: 1608 (1973).

9. Czok, R., and Eckert, L.: In: H. U. Bergmeyer: Methods of Enzymatic Analysis, pp. 229-233 (Academic Press, New York, 1965).

10. Dawkins, M. J. R.: Biochemical aspects of developing function in newborn mammalian liver. Brit. Med. Bull. 22: 27 (1966).

11. Dymsza, H. A., Czajka, D. M., and Miller, S. A.: Influence of artificial diet on weight gain and body composition of the neonatal rat. J. Nutr., 84: 100 (1964).

12. Eisenstein, A. B., and Strack, I.: Effect of high protein feeding on gluconeogenesis in rat liver. Diabetes, 20: 577 (1971).

13. Foster, D. O., Ray, P. D., and Lardy, H. A.: Studies on the mechanism underlying adaptive changes in rat liver phosphoenolpyruvate carboxykinase. Biochemistry, 5: 555 (1966).

14. Gehrke, G. W., and Stalling, D. L.: Quantitative analysis of the twenty natural protein amino acids by gas-liquid chromatography. Sep. Sci., 2: 101 (1967).

15. Good, C. A., Kramer, H., and Somogyi, M.: The determination of glycogen. J. Biol. Chem., 100: 485 (1933).

16. Goswami, M. N. D., and Chatagner, F.: Starvation-induced adaptation of rat liver tyrosine-transaminase and serine dehydratase. Experientia, 22: 370 (1966).

17. Hahn, P., and Greenberg, R.: The development of pyruvate kinase, glycerol kinase and phosphoenolpyruvate carboxykinase activities in liver and adipose tissue of the rat. Experientia, 24: 428 (1968).

18. Hahn, P., and Koldovsky, O.: International Series of Monographs in Pure and 
Applied Biology, Vol. 33. (Oxford, London, 1964).

19. Hahn, P., and Koldovsky, O.: Utilization of nutrients during Postnatal Development, (Oxford, Pergamon Press, 1966).

20. Hanson, R. W., and Garber, A. J.: Phosphoenolpyruvate carboxykinase. I. Its role in gluconeogenesis. Amer. J. Clin. Nutr., 25: 1010 (1972).

21. Hoy, P. A.: Diuresis in newborn rat given intravenous water or salt solution. Proc. Soc. Exp. Biol. Med., I22: 358 (1966).

22. Illnerova, H.: Urea formation in rats during postnatal development. Biol. Neonat., 9: 197 (1966)

23. Illnerova, H.: The development of arginase and ornithine transcarbamylase activities in the liver of rats. Physiol. Bohemoslov., I5: 19 (1966).

24. Kornhauser, D., Adam, P. A. J., and Schwartz, R.: Glucose production and utilization in the newborn puppy. Pediat. Res., 4: 120 (1970).

25. Lardy, H. A., Foster, D. O., Young, J. W., Shrago, E., and Ray, P. D.: Hormonal control of enzymes participating in gluconeogenesis and lipogenesis. J. Cell. Comp. Physiol., 66: 39 (1965).

26. Miller, S. A.: Protein metabolism during growth and development. In: H. N. Munro: Mammalian Protein Metabolism, pp. 183-233 (Academic Press, New York, 1969).

27. Miller, S. A.: Nutrition in the neonatal development of protein metabolism. Fed. Proc., 29: 1497 (1970).

28. Miller, S. A., and Allison, J. B.: The dietary nitrogen requirements of the cat. J. Nutr., 64: 493 (1958).

29. Miller, S. A., and Dymsza, H. A.: Artificial feeding of neonatal rats. Science, 141: 517 (1963)

30. Munro, H. N.: Role of amino acid supply in regulating ribosome function. Fed. Proc., 27: 1231 (1968).

31. Rogers, Q. R., and Harper, A. E.: Amino acid diets and maximal growth in the rat. J. Nutr.. 87: 267 (1965)

32. Schaub, J., Gutmann, J., and Lippert, H.: Developmental changes of glycolytic and gluconeogenic enzymes in fetal and neonatal rat liver. Horm. Metab. Res., 4: 110 (1972).

33. Short, J., Armstrong, N. B., Zemel, R., and Lieberman, I.: A role for amino acids in the induction of deoxyribonucleic acid synthesis in liver. Biochem. Biophys. Res. Commun., 50: 430 (1973).

34. Tannenbaum, S. R.: The metabolism in vivo of 2,4-dimethylheptanoic acid. Ph.D. Thesis, M. I. T., Cambridge, Mass. (1962).

35. Thorndike, J.: Comparison of the levels of three enzymes in developing livers of rats and mice. Enzyme, 13: 252 (1972).

36. Vavrousek, E.: The involvement of free amino acid pools in the regulation of protein synthesis in the neonatal rat liver (Sc.D. thesis, M. I. T., Cambridge, Mass., 1974).

37. Vavrousek-Jakuba, E., and Miller, S. A.: Effect of starvation on protein synthesis in neonatal rat liver. J. Nutr. 105: 1326 (1975)

38. Vavrousek-Jakuba, E., Miller, S. A., and White, P. K.: Developmental changes in the distribution of rat liver ribosomes in response to dietary manipulation. $\mathbf{J}$. Nutr., 105: 389 (1975).

39. Vernon, R. G., Eaton, S. W., and Walker, D. G.: Carbohydrate formation from various precursors in neonatal rat liver. Biochem. J., 110: 725 (1968).

40. Vernon, R. G., and Walker, D. G.: Changes in activity of some enzymes involved in glucose utilization and formation in developing rat liver. Biochem. J., 106: 321 (1968).

41. Vernon, R. G., and Walker, D. G.: Glucose metabolism in the developing rat Studies in vivo. Biochem. J., 127: 521 (1972).

42. Vernon, R. G., and Walker, D. G.: Gluconeogenesis from lactate in the developing rat. Biochem. J., 127: 531 (1972).

43. White, P. K., and Miller, S. A.: Design of a metabolic cage for infant rats. Lab. Anim. Sci., 25: 344 (1975).

44. Yeung, D., and Oliver, I. T.: Gluconeogenesis from amino acids in neonatal rat liver. Biochem. J., 103: 744 (1967).

45. Yeung, D., Stanley, R. S., and Oliver, I. T.: Development of gluconeogenesis in neonatal rat liver. Effect of triamcinolone. Biochem. J., 105: 1219 (1967).

46. The diet was prepared according to Miller and Allison (28). Composition in grams per kg of dry diet: casein, 250; dextrose, 172; sucrose, 167; dextrine, 172; corn oil, 150; salt mix (31), 40; choline chloride $(50 \% \mathrm{w} / \mathrm{v}), 4 \mathrm{ml}$; agar, 35; distilled water, 1,000; vitamin mix, 10 . Composition of vitamin mix in grams: vitamin $\mathrm{A}$ acetate $+\mathrm{D}_{2}(325,000 \mathrm{IU} \mathrm{A} / 32,500 \mathrm{IU} \mathrm{D}), 2.0$; vitamin E acetate $(250 \mathrm{U} / \mathrm{g}), 80.0$; vitamin $\mathrm{K}, 1.0$; thiamine $\mathrm{HCl}, 2.0$; riboflavin, 4.0 ; niacin, 10.0 ; vitamin $\mathrm{C}, 40.0$; pyridoxine $\mathrm{HCl}, 2.0 ; p$-aminobenzoic acid $(p \mathrm{ABA}), 20.0$; biotin, 0.10 ; Ca pantothenate, 10.0; folic acid, 0.4; inositol, 40.0; vitamin $\mathrm{B}_{12}$, 10.0; sucrose, 1780.54 .

47. Composition in grams per $\mathrm{kg}$ of dry diet: casein, 354 ; dextrose, 41 ; sucrose, 33 ; dextrine. 41; corn oil, 442; remainder as in note (46).

48. New England Nuclear, Boston, Mass.

49. Starvation was imposed for 4,15 , or $48 \mathrm{hr}$, respectively, for the three ages. The rationale for the starvation periods selected is presented under Discussion.

50. Composition in grams: Hammarsten casein, 5.0; nonfat dry milk, 15.0; vitamin mix, 2.0 ; mineral mix, 0.5 ; choline chloride $(50 \% \mathrm{w} / \mathrm{v}), 0.08 \mathrm{ml}$; corn oil, 11.0 ; distilled water, 66.5. Vitamin mix, composition in grams: vitamin A acetate + $\mathrm{D}_{2}\left(325,000 \mathrm{IU} \mathrm{A} / 32,500 \mathrm{IU} \mathrm{D} \mathrm{D}_{2}\right), 0.6000$; vitamin $\mathrm{E}$ acetate, 8.0000; vitamin $\mathrm{K}, 0.0100$; thiamine $\mathrm{HCl}, 0.1060$; riboflavin, 0.8850 ; niacin, 2.2000; vitamin $\mathrm{C}$ 5.2500 ; pyridoxine $\mathrm{HCl}, 0.0756$; $p \mathrm{ABA}, 0.0100$; biotin, 0.0076 ; $\mathrm{Ca}$ pantothenate, 0.8360; folic acid, 0.0025; inositol, 62.3000; vitamin $B_{12}, 2.4800$; glucose, 417.2373. Mineral mix, composition in grams: Ca lactate, 1240.0000; Ca gluconate, 193.5000; KCl, 98.0000; $\mathrm{NaCl}, 68.50000 ; \mathrm{CuSO}_{4} \cdot 5 \mathrm{H}_{2} \mathrm{O}, 0.8630$ $\mathrm{CoSO}_{4} \cdot 7 \mathrm{H}_{2} \mathrm{O}, 0.0240 ; \mathrm{NaF}, 0.0596 ; \mathrm{KI}, 0.0675 ; \mathrm{FeSO}_{4} \cdot 7 \mathrm{H}_{2} \mathrm{O}, 1.5290$; $\mathrm{MgSO}_{4} \cdot 7 \mathrm{H}_{2} \mathrm{O}, \quad 176.5000 ; \mathrm{ZnCl}_{2}, \quad 1.0525 ; \quad\left(\mathrm{NH}_{4}\right)_{6} \mathrm{MO}_{7} \mathrm{O}_{24}, \quad 0.0129 ;$ $\mathrm{MnSO}_{4} \cdot \mathrm{H}_{2} \mathrm{O}, 0.0139$.

51. Delmar Scientific Co., Maywood, Ill.

52. Worthington Biochemicals, Freehold, N. J.

53. The technical assistance of Yukio Ichinose, M. D., in the PEPCK analyses is gratefully acknowledged.

54. Contribution no. 2329 from the Department of Nutrition and Food Science, M.I.T.

55. This research was supported by National Institutes of Health Grant no. GM-10337.

56. Requests for reprints should be addressed to: Patricia K. White, Ph.D., Department of Nutrition, Simmons College, 300 The Fenway, Boston, Mass. 02115 (USA).

57. Accepted for publication October 29, 1975.

\title{
Experimental Analysis of Developing Hemopoiesis in Fetal Bone Marrow
}

\author{
R. J. HAAS, ${ }^{(23)}$ D. HOELZER, E. KURRLE, B. LANDENBERGER, AND U. WINKLER \\ Department of Pediatrics, Hematology Division, University of Munich, Munich, and Department of Clinical Physiology, University of Ulm, \\ Ulm/Donau, Federal Republic of Germany
}

\section{Extract}

1. We have used fetal rats to study the following aspects of the development of hemopoiesis: $(a)$ content of hemopoietic stem cells in fetal bone marrow, liver, and peripheral blood and $(b)$ origin of hemopoietic cells in the developing mammalian bone marrow.
2. In the studies we utilized the diffusion chamber technique to study the content of stem cells committed to granulopoiesis. The number of myelopoietic stem cells in liver peripheral blood and in "bone marrow" of 18-day-old rats is nearly identical. Since in "bone marrow" a considerable number of peripheral blood cells are present in the vessels at that time, whereas extravascular cells con- 